decision will rest with the Court of Electors, through the Dean.

(2) Higher Professional Training in Psychiatry. Part-time higher training is acceptable under the following conditions:

(a) Part-time training will be dealt with as an individual circumstance. The Joint Committee on Higher Psychiatric Training will consider each application separately.

(b) Training must be undertaken in posts approved by the Joint Committee in the Senior Registrar grade (or, exceptionally, other grades). Supernumerary appointments will be acceptable if approved by the Joint Committee.

(c) The total training period should be equivalent in duration and quality to the normal whole-time training requirement. This does not mean that it is necessary to demand of part-time trainees that they should complete exactly the pro-rata length of training. (Allowance can be be made for commitment to the specialty, and the use of non-sessional

\section{SUBSCRIPTIONS AND THE APPEAL}

Some overpayments of subscriptions occurred during 1979 mainly because members' banks failed to cancel old standing orders. Instead of agreeing to have a refund some members donated the excess to the Appeal Fund. I am delighted to find that the total of these sundry donations is nearly $£ 900$, and on behalf of the College I would like to thank everyone concerned for their generosity. A few of the members who have reached $\mathbf{4 0}$ years membership of the College and the RMPA kindly agreed to divert their annual subscription payments to the Appeal Fund, and I should like to extend to them my gratitude for this action.

Just recently one of the Divisions donated the surplus from its Conference to the Appeal which amounted to almost $£ 200$. This kind of zeal is very satisfying, but we still need your support, and early in 1980 the Appeal Committee will probably be looking at other ways of raising money in an effort to establish a fairly regular income so that individual projects can be considered annually and, if financially viable, embarked upon.

A covenanted donation of $£ 10$ a year from just 500 members would net $£ 7,500$ annually with the Income Tax refund which the College can claim. There is a loose-leaf Deed of Covenant form in this issue. Why not fill it in now and make 1980 the year of the College?

C. M. B. PARE, Honorary Treasurer time for such activities as reading and continuing study.)

(d) Part-time higher training should not ordinarily be less than half-time. Higher fractions would be acceptable and the total period of training would be adjusted accordingly at the discretion of the Joint Committee. Part-time higher training must include clinical experience and responsibilities, administrative duties, teaching responsibilities towards junior trainees, training in necessary special techniques with Consultant supervision, and opportunities for research in all respects similar to the experience of those undertaking whole-time higher training. It should also include the same or similar resident and 'on-call' commitments as those for full-time trainees, but on a prorata basis.

DESMOND POND, President: Royal College of Psychiatrists

KENNETH RAWNSLEY, Chairman: Joint Committee on Higher Psychiatric Training

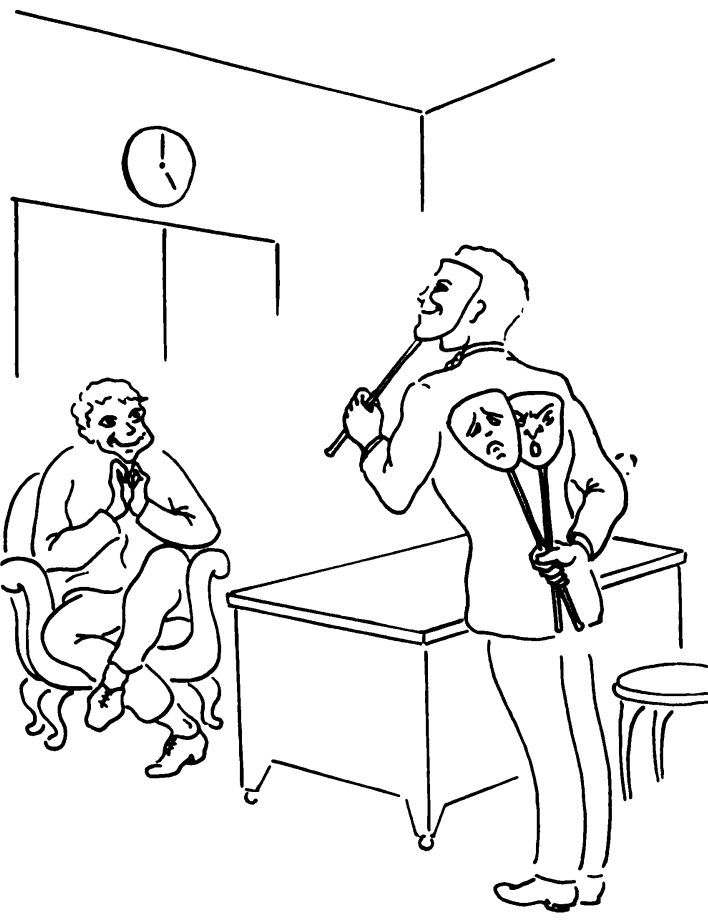

Psychiatrists at Work: Psychotherapy.

R. de Alarcon 